\title{
Improving the efficiency of timber sawing process by increasing reliability of attachments for forestry equipment
}

\author{
M. Zyryanov, A. Saltanov*, A. Davydenko, and E. Dozhdev \\ Lesosibirsk branch of FSBEI of Higher Education 'Siberian State Technological University of Science \\ and Technology named after Academician M.F. Reshetnev’, 29 Pobedy str., Lesosibirsk, 662543, \\ Russian Federation
}

\begin{abstract}
The current state of the timber industry complex and the prospects for its further development indicate the need to revise the approach to organizing logging process as a resource-saving, economically and environmentally sound process. Rational nature management and careful use of available forest resources come to the fore. Today, logging machines are an integral part of logging, and technical condition of the equipment of these machines has a direct impact on their productivity, quality of round timber and amount of sawmill waste received. The paper presents a design solution that makes it possible to increase efficiency of forest machines in freezing temperatures, which increases their productivity and the quality of the resulting roundwood by reducing the generated logging waste.
\end{abstract}

The timber industry includes several key operations: harvesting, transportation and processing of the material. Among all operations, harvesting is the most labor-intensive and requires the greatest amount of resources to perform [1].

As a result of development of mining industry, mechanization of all types of equipment and modernization of the technical park of logging industries are taking place. For example, wood harvesting by manual felling with a saw and an ax has significantly decreased; gasoline and electric chain saws are replacing them, and high-tech machines for forestry operations such as harvesters are becoming the main production force.

Analysis of literature sources showed that the bulk of the forest fund is located in the Siberian and Baikal (Irkutsk) regions [2]. Climatic and territorial conditions of the region imply that logging process takes place mainly in conditions of freezing temperatures, often falling below $-40^{\circ} \mathrm{C}$, and the duration of them can be more than 6-7 months a year. Operating conditions of the equipment are extremely difficult; during work, certain problems arise in the weak points of structures, and attachments are those weak points. Thus, the harvester head is susceptible to icing, which leads to equipment operation in emergency mode, a decrease in productivity of the harvester and failure of the head itself. Since the equipment does not work correctly, the technological process of harvesting is disrupted, which leads to an increase in the number of rejects, and, consequently, the amount of forestry waste, which negatively affects the environment.

*Corresponding author: tiomka_97@mail.ru 
At present, the methods of eliminating icing are reduced to its physical removal and influencing it with thermal devices or open fire [3]. However, with the mechanical method, the problem of limited access to the places with ice build-up arises, and the thermal method often leads to failure of electrical control units.

In the course of fight against icing, several solutions have been found. Thus, to combat freezing of bulk material to the walls and bottom of the body, a body with a heating device was developed, containing a system of channels in the bottom and sides of the body, communicating with the exhaust tract. The main disadvantage of this invention is inability to continuously heat the equipment while performing work on the move, as well as the lack of a purge system after stopping the engine.

The study of heating attachments of forestry equipment is based on a complex of modern research methods, including mathematical modeling and statistical analysis. To assess temperature indicators and the duration of exposure to freezing temperatures, the collection of climatic data and further statistical analysis of the results were carried out. For data collection, the cutting areas of the Angara-Yenisei region were selected. The object of research was a logging machine equipped with a multifunctional harvester head and a manipulator.

When measuring the temperature indicators, the following parameters were taken into account: the ambient temperature, the inner and outer diameters of the tube, the temperature of the gas in the tube, and the temperature of the outer wall of the tube. To calculate the thermal performance of exhaust gases, the calculation method for diesel engines was used [4]. After processing measurement results, graphs of the dependence of the outer wall temperature of the heating pipe on the ambient temperature (Fig. 1) and on its diameter (Fig. 2) were built.

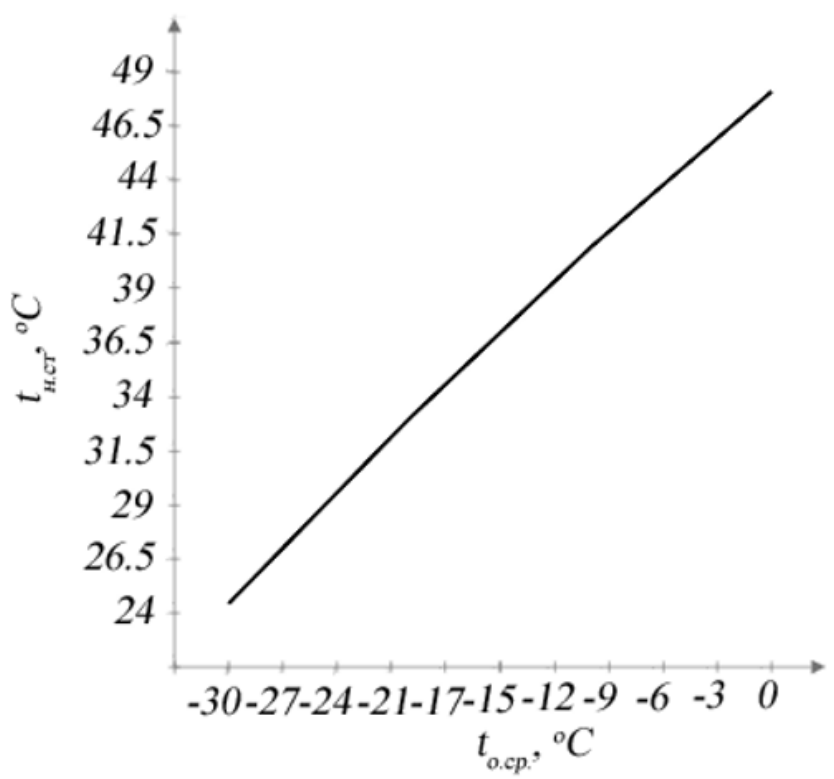

Fig. 1. Dependence of the temperature of the outer wall of the heating pipe on the ambient temperature at $d_{\text {н.ст }}=25 \mathrm{~mm}$. 


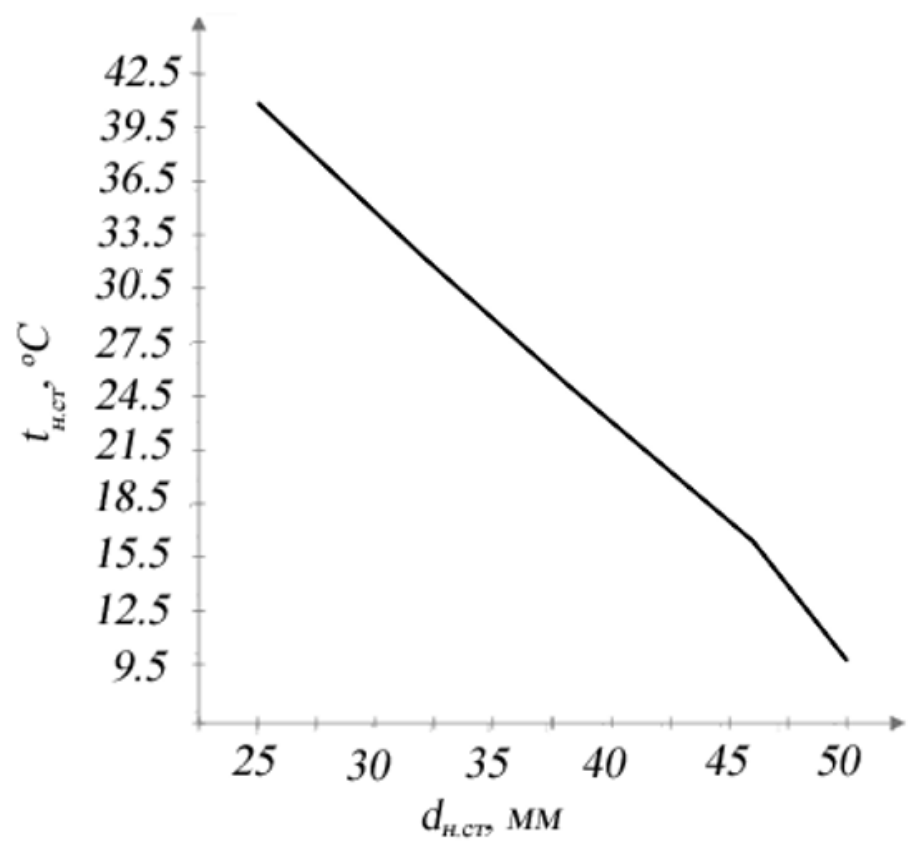

Fig. 2. Dependence of the temperature of the outer wall of the heating pipe on its diameter at $t_{\text {o.cp. }}=$ $-10^{\circ} \mathrm{C}$

When processing the thermal calculation results, an equation was obtained that describes the dependence of the surface temperature of the heating element on its geometric characteristics and the ambient temperature:

$$
\begin{gathered}
t_{\text {н.тр }}=86,776+0,519 \cdot t_{\text {о.ср }}-0,003 \cdot t_{\text {о.сp }}{ }^{2}-1,391 \cdot d_{\mathrm{H}}+0,0035 \cdot d_{\mathrm{H}}{ }^{2}+ \\
0,0062 \cdot t_{\mathrm{o.cp}} \cdot d_{\mathrm{H}}
\end{gathered}
$$

The calculations have confirmed that all the coefficients of the regression equations are significant.

The result of the research is development of a heating design for a multifunctional harvester head, which, during harvesting in the period of freezing temperatures, will heat the free space between the frame and the attached units (working mechanisms).

The principle of operation of the harvester head heating system (Fig. 3) is that the exhaust gases obtained as a result of operation of the internal combustion engine (1), under pressure enter the exhaust manifold (2), then the exhaust pipe, where the cutter (3) is located, separating gas flow in two: one goes further along the exhaust system, the other goes directly to the heating system. After entering the pipe of the heating structure (6), the gases enter the pressurization system (5), which is electrically driven and reduces the temperature of the gases to the optimum. Further movement of gases occurs through a system of pipes $(6,8,10,12)$ and flexible hoses $(7,9,11,13)$ connecting the pipes in places where it is necessary to ensure mobility of the structure. Directly in the harvester head there is a serpentine tube that transfers heat to the harvester head. 


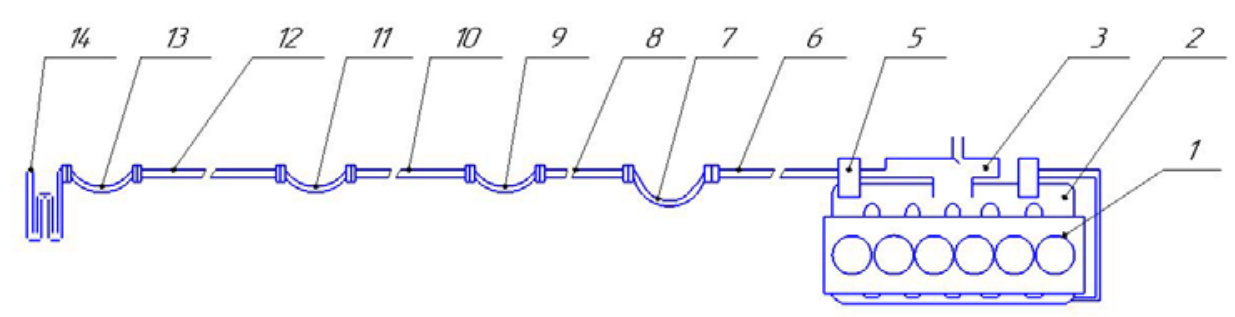

Fig. 3. Harvester head heating system diagram

For a better understanding of the heating element location, we indicate the location of the heating system structure directly in the harvester head (Fig. 4):
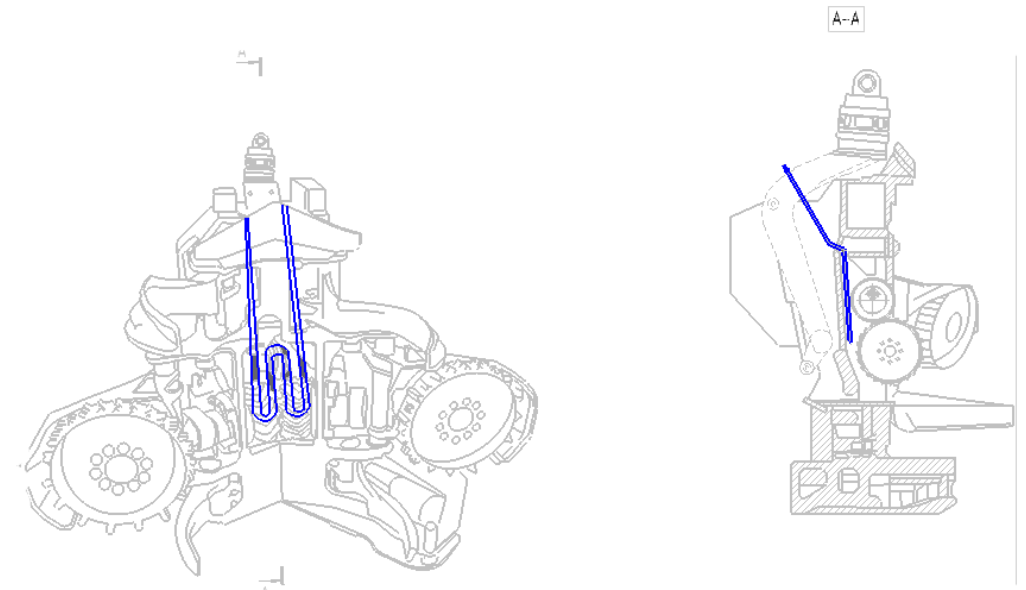

Fig. 4. Heating system design in the harvester head

The return of gases to the exhaust system after the coil is carried out in the opposite direction through the pipes installed in conjunction with the pipes for supplying the heating system.

Thus, the proposed heating design prevents freezing of the attachments. This will reduce the downtime and emergency operation time of equipment, which, in turn, entails an increase in the daily productivity of the machine. Also, softening the operating conditions will extend the life of the equipment. In addition, reduction in the emergency operation time of the harvester head leads to an increase in the quality of roundwood processing, which means a decrease in rejects and, accordingly, in the amount of forestry waste.

The project 'Improving the efficiency of technological machines in the working conditions of the Arctic and the territories of the Far North' is supported by the Regional Science Foundation

\section{References}

1. Zozulya V.V., Sakhanov V.V., Medvedev S.O., Bezrukih Y.A. and Romanchenko O.V. Osobennosti upravleniya modernizaciej promyshlennosti $v$ lesnom komplekse [The features of industrial modernization management in forest complex] International Multidisciplinary Scientific Geo Conference Surveying Geology and Mining Ecology Management, SGEM 17, 2017, Ecology, Economics, Education and Legislation p.p. 927934. 
2. Gritsuk I., Volkov V., Mateichyk V., Gutarevych Y. et al. The evaluation of vehicle fuel consumption and harmful emission using the heating system in a driving cycle, 2017, SAE Int. J. Fuels Lubr 10 pp. 236-248.

3. Andris K.B. Track heating of oil products during transportation by road. Bulletin of the Astrakhan State Technical University. 2008, No. 6, pp. 192-194.

4. Use of exhaust gas heat for heating the car interior [Electronic resource] / Access mode: https://sibac.info.

5. Zyryanov M.A. et al. IOP Conf. Ser.: Earth Environ. 2021, Sci. 677. 